\title{
Effects of Monosodium Glutamate on the Kidney of Male Adult Albino Rat and the Possible Protective Role of Vitamin C
}

\author{
MOHAMED A. DOSUKY, M.D.*; DORREIA A. ZAGHLOL, M.D.**; SALWA M. OUIES, M.D.*** and \\ HANAA A. ABD EL-NAEIM, M.Sc. $* * *$ \\ The Department of Anatomy \& Embryology, Faculty of Medicine, Alminia* \& Assiut** Universities and \\ The Department of Human Anatomy \& Embryology, Faculty of Medicine, Sohag University***
}

\begin{abstract}
Background: Monosodium glutamate is used commercially as a food additive and is commonly marketed as a flavour enhancer. It is now used by most fast-food chains and in many food-stuffs, in particular, processed foods. Vitamin C (ascorbic acid) is a very important and powerful antioxidant that works in aqueous environment of the body Vitamin C protects against common cold. Beneficial effects in conditions such as cancer, vascular disease, cataracts, diabetes, asthma, arthritis, Parkinson's disease, autism and depression have also been suggested.

Aim of the Work: The aim of this study was to study the potential protective effect of Vitamin $\mathrm{C}$ on kidney damage caused by monosodium glutamate in adult male rats.

Material and Methods: Sixty adult albino rats were used. The animals were equally divided into three groups each of them consists of 20 rats: Group I: "Control" were given $1 \mathrm{ml}$ of saline daily by oral route "for one month. Group II: Were given monosodium glutamate $(4 \mathrm{gm} / \mathrm{kg}$ of body weight/day, dissolved in saline orally) for one month. Group III: Were given Vitamin C (500mg/kg of body weight /day, orally) then after 2 hours were given monosodium glutamate $(4 \mathrm{gm} / \mathrm{kg}$ of body weight/day, dissolved in saline orally) for one month.

At the end of the experiment, the rats were anaesthetized by ether then perfused with saline then with the appropriate fixator (formalin 10\%). The abdomens were opened and the kidneys of the control and treated animals were extracted, cut, and processed for light and transmission electron microscopic studies.
\end{abstract}

Results: Monosodium Glutamate (MSG) markedly destructed glomeruli and tubules of the kidney at light and electron microscopic examination and morphmetric studies Administration of Vitamin $\mathrm{C}$ could attenuate these changes.

Conclusion: MSG caused degenerative changes in the cortical glomeruli and tubules. On the addition of Vitamin C can decrease that toxic effects of MSG.

Key Words: Kidney-Monosodium glutamate - Vitamin C.

Correspondence to: Dr. Mohamed A. Dosuky, The Department of Anatomy \& Embryology, Faculty of Medicine, Alminia University

\section{Introduction}

THE kidneys are highly vascularized, compound tubular glands that function to maintain the composition of body fluids at a constant level and to remove excretory wastes [1]. Monosodium Glutamate (MSG) is added to foods, it provides a flavoring function similar to naturally occurring free glutamate [2]. It is found in unlimited amounts in a wide variety of packaged foods such as processed meat and poultry, semi-preserved fish and fish products, food supplements [3]. Trade names of monosodium glutamate include Ajinomoto, Vetsin, Ac'cent and Tasting Powder [4]

MSG is a slow poison which hides behind dozens of names, such as natural flavouring and yeast extract. It is not a nutrient, vitamin, or mineral and has no health benefits. The part of MSG that negatively affects the human body is the "glutamate", not the sodium. The breakdown of MSG typically consists of $78 \%$ glutamate, $12 \%$ sodium, and about $10 \%$ water [5]

Vitamin C (L-ascorbic acid) is an essential micronutrient required for normal metabolic functioning of body [6]. In living organisms, ascorbate acts as an antioxidant by protecting the body against oxidative stress. It is a powerful reducing agent capable of rapidly scavenging a number of Reactive Oxygen Species (ROS) [7].

\section{Aim of the work:}

The aim of this work was to study the effect of MSG on the histological structure of the kidney and the possible protective role of Vitamin C. 


\section{Material and Methods}

The research was done in 2016. A total number of sixty adult male albino rats (average weight 180-200gm) were brought from the animal house of Sohag Faculty of Science. They were reared under-the standard conditions of feeding, lightdark ratio and temperature.

\section{Animal used:}

Group (I) [control group]:Were given $1 \mathrm{ml}$ of saline daily by oral route for one month.

Group (II) [monosodium glutamate treated group]: Were given monosodium glutamate (4 $\mathrm{gm} / \mathrm{kg}$ of body weight/day, dissolved in saline orally) for one month [8].

Group (III) [vitamin c-monosodium glutamate treated group]: Were given Vitamin C $(500 \mathrm{mg} / \mathrm{kg}$ of body weight of/day, orally) [9] then after 2 hours will be given monosodium glutamate $(4 \mathrm{gm} / \mathrm{kg}$ of body weight/day, dissolved in saline orally) for one month.

Monosodium glutamate was obtained from Morgan Company for Chemical Industry (Tenth of Ramadan City-Egypt). Vitamin C ( L-ascorbic acid ) was obtained from Egyptian pharmaceutical industries company. MSG and Vitamin C were in the form of powder, dissolved in saline and each rat was given $1.5 \mathrm{~cm}$ MSG and $0.5 \mathrm{~cm}$ Vitamin C orally via syringe (gastric tube).

At the end of the experiment, the rats were anaesthetized by ether then perfused with saline. The abdomens were opened and the kidneys of the control and treated animals were extracted, put in the appropriate fixator (Formalin 10\%), cut, and processed for light and transmission electron microscopic studies.

For light microscopic study: The specimens were fixed in $10 \%$ neutral buffered formalin and processed for light microscopic study to get paraffin sections of 6 ickness. Sections were stained with Haematoxylin and Eosin (H \& E) and Masson's Trichrome stain.

For Transmission Electron Microscopic study (TEM): Specimens were cut in small pieces and fixed in $2.5 \%$ glutaraldehyde for 24 hours. Then specimens were washed by sodium cocodylate buffer solution, postfixed in $1 \%$ osmium tetraoxide in sodium cacodylate buffer for two hours, then washed and dehydrated in ascending grades of alcohol, ehanol 30\%, 50\%, 70\%, 95\%. The specimens were embedded in Mollenhauer's EponAraldite formulation and the tissue blocks were polymerized in an oven. Blocks were trimmed with a razor blade and cutting was done by a glass knife in KLB ultramicrotome. Semithin sections were stained with Toluidine blue. Ultrastructural sections were mounted on copper grids, stained with Uranyl acetate and lead citrate and ultrathin sections were examined by transmission electron microscope (Jeol-1010) in Assiut University.

\section{Morphometric and statistical analysis:}

Estimation of the mean diameters of the renal glomeruli, proximal and distal convoluted tubules (at magnification 400) was done. Measurements were performed in Haematoxylin and Eosin $(\mathrm{H} \&$ E) sections, 2-3 sections per animal. In each section five measurements were obtained from five randomly chosen fields using image analysis system (digimizer version 3.7.2005-2010) med-calc software in the Anatomy Department at Sohag University.

\section{Statistical analysis:}

Statistical analysis of measurements of mean diameters of the glomeruli, proximal and distal convoluted tubules were done using SPSS soft ware Version 16. Variables were represented by mean $\pm \mathrm{SD}$ (mean \pm standard deviation of mean). One way ANOVA was used to compare the means of these variables between different groups. Finally the significance was considered according to the level of significance $p$-value as follows:

$p>0.05$ non significant.

$p \leq 0.05$ significant*.

$p \leq 0.01$ highly significant $* *$.

$p \leq 0.001(* * *) \rightarrow$ very high significant difference.

\section{Results}

\section{Group 1 (control group):}

Histological study:

By Light Microscopy, the renal cortex appeared formed of the renal corpuscle, proximal convoluted tubules and distal convoluted tubules (Figs. 1,2).

The renal corpuscle was formed of a tuft of capillaries surrounded by a double layer cup called Bowman's capsule. Bowman's capsule consisted of two layers. The outer parietal layer was formed of simple squamous epithelium while the inner visceral layer had modified epithelial cells called podocytes. The space between the two layers was called the urinary space (Figs. 1,2).

The proximal convoluted tubules appeared lined by cuboidal epithelium. The nuclei were spherical 
and basally located. The apical surface had a prominent brush border (Fig. 2).

The distal convoluted tubules were lined by cuboidal epithelium. The epithelial cells lacked the brush border. The nuclei were spherical and apically located (Fig. 2).

PAS stained sections showed a strong positive reaction in Bowman's capsules and in the basement membranes of proximal and distal convoluted tubules. The strong reaction in the brush borders of proximal convoluted tubules was seen (Fig. 3).

Examination of kidney sections of control rat stained with Masson's Trichrom's stain revealed minimal distribution of collagen fibers in the renal corpuscles and throughout the renal tubules (Fig. $4)$.

\section{Ultra structurally:}

The renal corpuscle appeared formed of a glomerular capillary and podocytes. The glomerular basement membranes (basal lamina between the capillary endothelium and the podcytes) appeared with normal thickness. The glomerular capillary was lined by endothelial cells. In between the endothelial cells, there were numerous fenestrations. The podocytes had numerous pedicles (foot processes) interdigitating with neighboring podocytes (Fig. 5).

The epithelial cells of proximal convoluted tubule appeared with well defined border. The nuclei were spherical with prominent nucleolus. The apical surface had a prominent brush border; the cytoplasm was filled with multiple mitochondria (Fig. 6).

The epithelial lining of distal convoluted tubules appeared cuboidal with well defined border. The nucleus was large well defined and spherical with prominent nucleolus, the cytoplasm was filled with multiple mitochondria (Fig. 7).

\section{Group II (rats treated by MSG):}

By LM, the renal cortex of the treated group showed small renal corpuscles with widened Bowman's spaces Fig. (8). Areas of haemorrhage and congestion were observed inside tubules, interstitial haemorrhage in intertubular spaces and partial destruction of the brush border of proximal convoluted tubules also were seen (Fig. 9). Vaculation of the cytoplasm of the proximal and distal convoluted tubules also noticed (Fig. 10).

PAS stained sections showed moderate positive reaction in Bowman's capsules and tubules. A weak reaction in the brush borders of proximal convoluted tubules was also seen (Fig. 11).

Masson's trichrome stained sections revealed massive degree of distribution of collagen fibers around renal tubules and malpigian corpuscles (Fig. 12).

\section{Ultra structurally:}

Ultrathin sections in the renal cortex of rats treated with MSG, the glomerular basement membranes appeared thickened, destructed podocytes also noticed, foot processes of the podocytes appeared normal (Fig. 13).

The epithelial cells of proximal convoluted tubule had ill defined borders, destructed apical part and brush border of the cell with multiple vacuoles. The cell rest on relatively thick basement membrane, multiple swollen mitochondria were also observed, the cell contained heterochromatic rounded nucleus. Other area had multiple closely packed microvilli forming the brush border were also noticed (Fig. 14).

The lining epithelial cells of distal convoluted tubules appeared with ill defined border, destructed cytoplasm with multiple vaccuolation, swollen and destructed mitochondria also appeared, irregular border heterochromatic nuclei, the cells appeared resting on thick basement membrane (Fig. 15).

\section{Group (III) (Vitamin C $+M S G)$ :}

LM study; the renal cortex of Vitamin C supplemented group showed restoration of normal shape of renal corpuscles, relatively normal capsular space, some glomeruoli appeared irregular in shape with mild dilatation of urinary spaces (Figs. 16,17).

Partial loss of the brush border of the proximal convoluted tubules were noticed. Distal convoluted tubules were relatively normal, some vacuolation of cells of convoluted tubules were also seen Figs. $(16,17)$. Mild haemorrhage in interstitial space still present (Fig. 16).

PAS stained sections showed moderate positive reaction in Bowman's capsule and convoluted tubules. A variable strong reaction in the brush borders of proximal convoluted tubules was seen (Fig. 18).

Masson's trichrome stain revealed more or less reduction in the amount of collagenous fibers as compared with the MSG treated group (Fig. 19). 


\section{Ultra structurally:}

Ultrathin sections in the renal cortex of Vitamin C supplemented + MSG showed restoration of normal shape of glomeruoli, restoration of the normal thickness of glomerular basement membranes. The podocytes with normal shape and had numerous pedicles (foot processes). The glomerular capillary was lined by endothelial cells. In between the endothelial cells, there were numerous fenestrations (Fig. 16).

The lining epithelial cells of proximal convoluted showed restoration of their normal shape, the cells showed intact brush border, cells showed euchromatic nuclei with prominent nucleolus and multiple swollen mitochondria still present, cells were seen resting on normal basement membranes (Figs. 21).

The lining epithelial cells of distal convoluted tubules were resting on a relatively normal thickness basement membrane. The cells restore their normal shape, they had euchromatic nuclei with



Fig. (1): A photomicrograph of a section of kidney of control rat showing; renal glomeruli (G) urinary space (U), proximal convoluted tubules (P) and distal convoluted tubules (D). (H \& E X400).

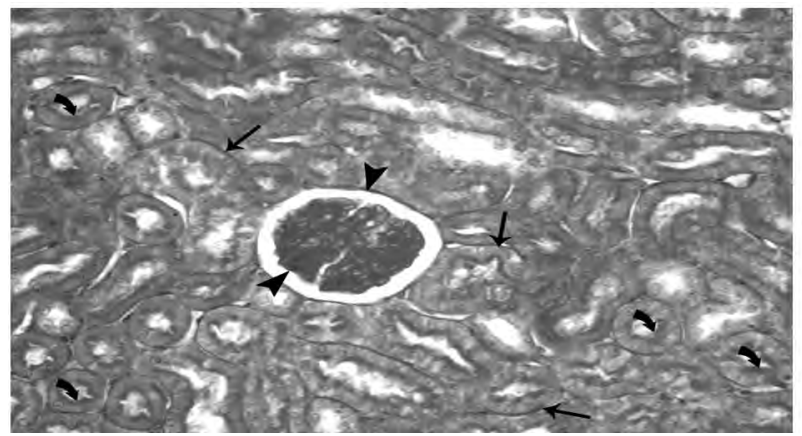

Fig. (3): A photomicrograph of a section in the renal cortex of adult control rat showing a strong positive reaction in Bowman's capsules (arrow heads), basement membrane of proximal and distal convoluted tubules (arrows) and the brush borders of proximal convoluted tubules (curved arrows). (PAS $\mathrm{X} 400$ ) well defined border and the cytoplasm was filled with mitochondria (Fig. 22).

\section{Morphometric study:}

-Diameter of Glomerulus: (Table 1), Diagram (1): Mean glomerulus diameter in Group II (551.7459 pixels) showed a non significant change $(p>0.05)$ when compared with Group I (564.0786) and Group III (578.2498 pixels).

- Diameter of proximal convoluted tubules: (Table 1), Diagram (1): Mean proximal convoluted tubules diameter in Group II (326.9511 pixels) showed a highly significant $(p=0.000)$ increase when compared with Group I (261.6362 pixels) and Group III (323.5516 pixels).

- Diameter of distal convoluted tubules: (Table 1), Diagram (1): Mean distal convoluted tubules diameter in Group II (668.6593 pixels) showed a highly significant $(p=0.000)$ increase when compared with Group I (380.1822 pixels) and Group III (406.2594 pixels).

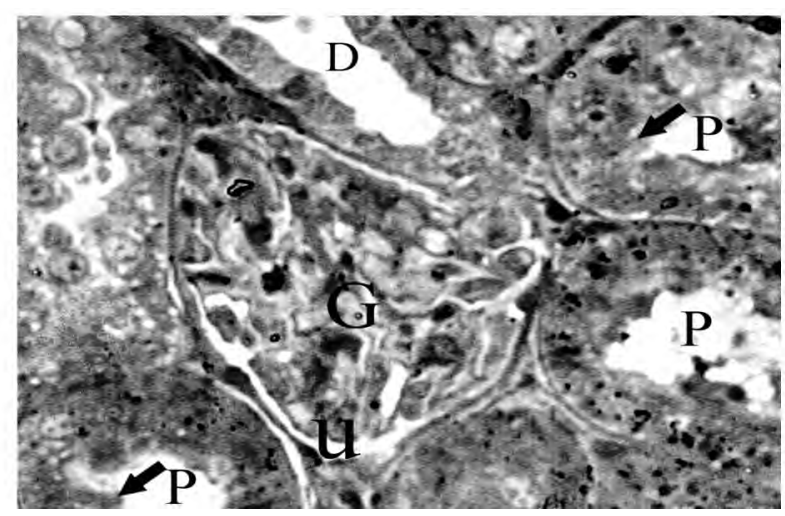

Fig. (2): A photomicrograph of semithin section in kidney of control rat showing; renal glomerulus $(\mathrm{G})$, urinary space $(\mathrm{U})$ and proximal convoluted tubules $(\mathrm{P})$ with brush borders (thick arrow). (Toluidine blue X1000).

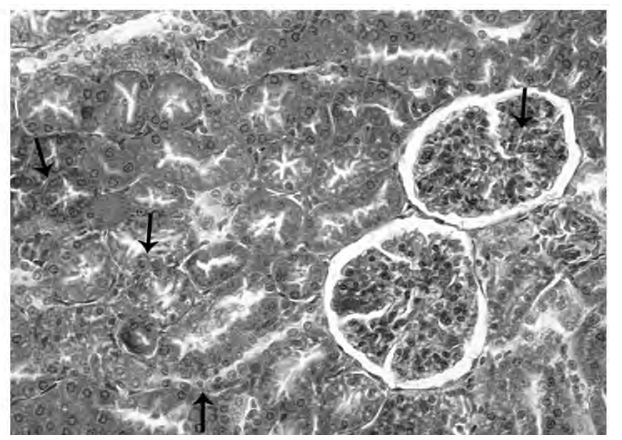

Fig. (4): A photomicrograph of a section of kidney of control rat showing normal distribution of collagenous fibers in the renal corpuscles and throughout renal tubules (arrows). (Masson Trichrome stain. X400). 


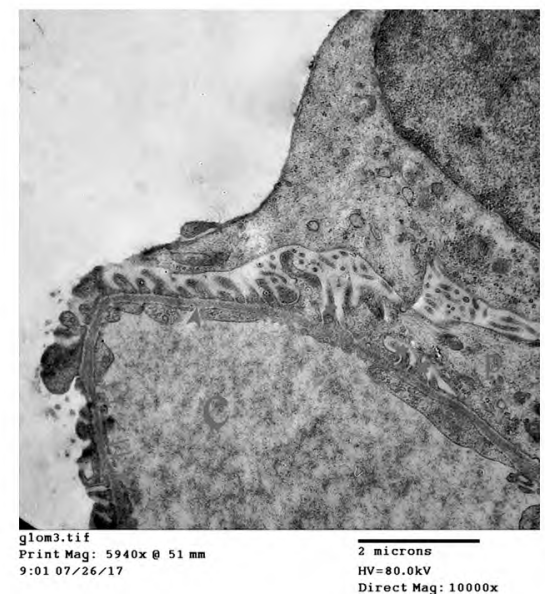

Fig. (5): An electron micrograph of a portion of renal glomerulus in kidney of control rat showing; a glomerular capillary (C) and an adjacent podocyte (P). The capillary is lined by endothelial cells separated by fenestrations (thin arrows). The capillary endothelium rests on the basal lamina (arrow head). The podocyte has multiple pedicles (asterisks). (X10,000).

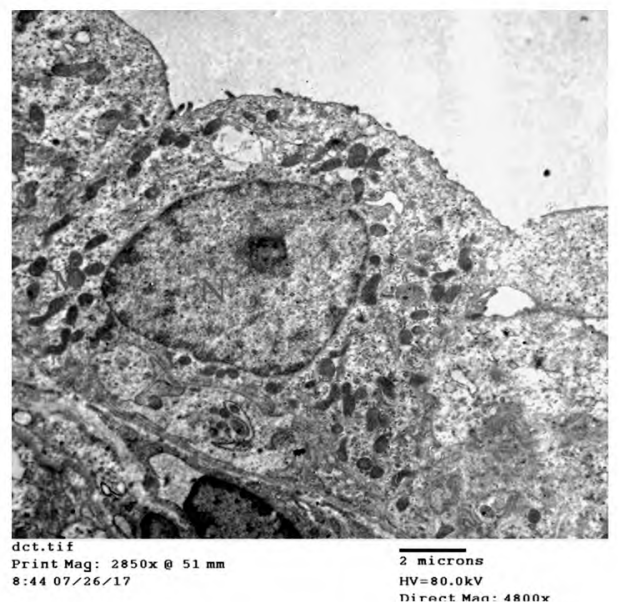

Fig. (7): An electron micrograph of a section in renal cortex showing epithelial lininning of distal convoluted tubule of control rat appeared with well defined border and showing with large well defined euchromatic nucleus $(\mathrm{N})$ with prominent nucleolus $(\mathrm{n})$, the lining epithelial cells of distal convoluted tubules resting on a basement membrane (arrow head) and multible mitochondia (M). (X4800).

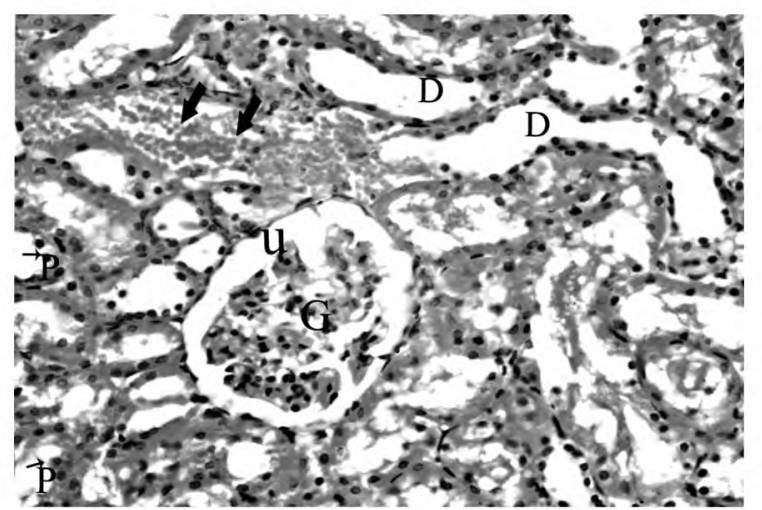

Fig. (9): A photomicrograph of a section of kidney of treated rat (Group II) showing proximal convoluted tubules (P) with partial destruction of their brush borders (thin arrows),dilated distal convoluted tubules (D), interstitial haemorrhage in the intertubular spaces (thick arrows), N.B: Glomerulous (G) and urinary space (U). (H \& E X400).

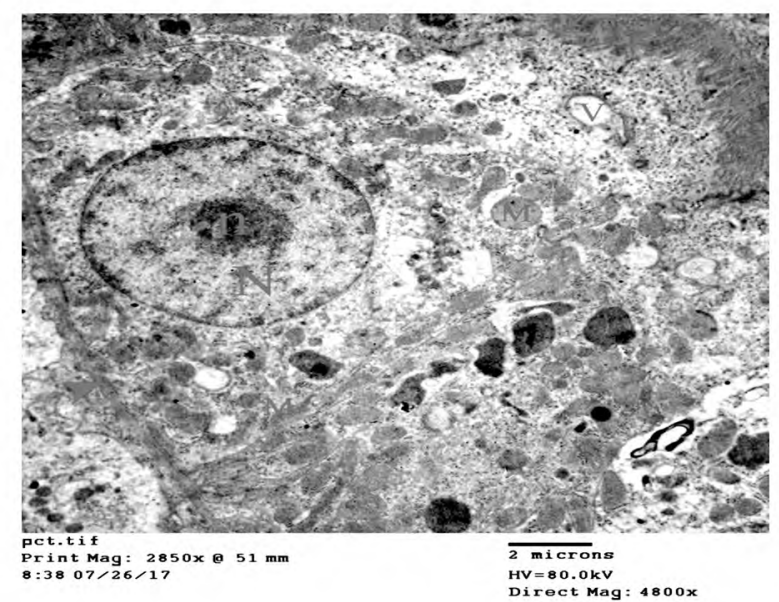

Fig. (6): An electron micrograph of a section of renal cortex showing epithelial cells of proximal convoluted tubule of control rat with well defined border showing; a large rounded euchromatic nucleus $(\mathrm{N})$, prominent nucleolus (n), multiple mitochondria $(\mathrm{M})$ appeared within cytoplasm with apical vesicles (V), apical microvilli (arrow) and basal lamina (arrow head). (X4800).

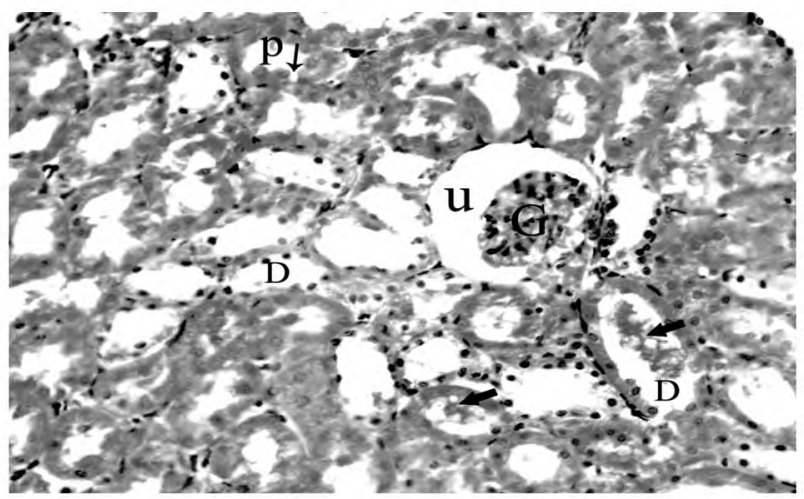

Fig. (8): A photomicrograph of a section of kidney of treated rat (Group II) showing; proximal convoluted tubules (P) with partial destruction of their brush borders (thin arrow), haemorrhage (thick arrows) appeared in the distal convoluted tubules (D), Glomerular atrophy (G) and dilated urinary space (U). (H \& E X400).

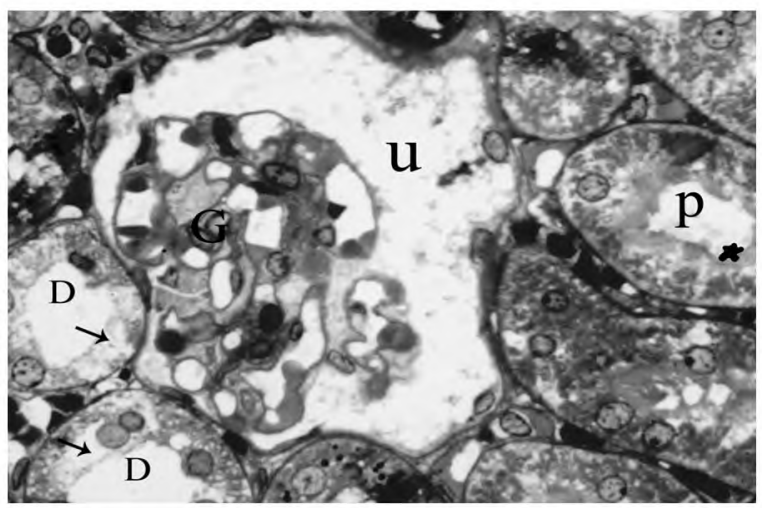

Fig. (10): A photomicrograph of semithin section in kidney of treated rat (Group II) showing proximal convoluted tubule $(\mathrm{P})$ with destructed cells (asterisk), distal convoluted tubules (D) with vacuolation of the cytoplasm of their cells (arrows), shrunken glomerulus (G) and wide urinary space (U). (Toluidine blue X1000). 


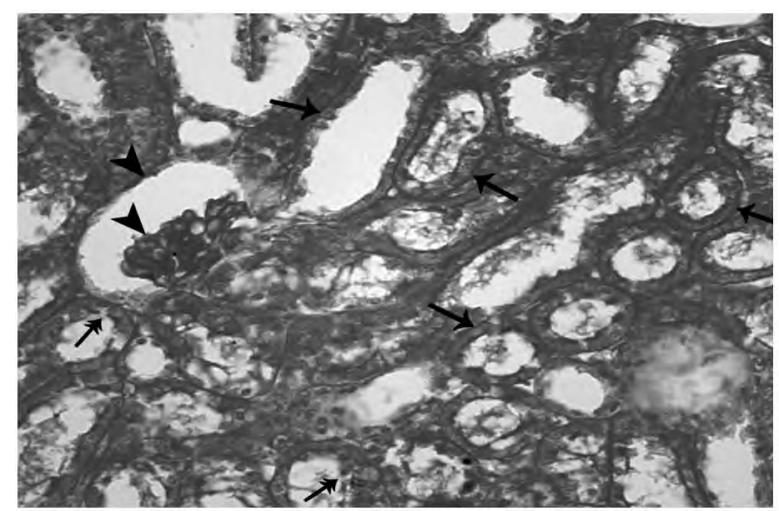

Fig. (11): A photomicrograph of a section in the renal cortex of adult treated rat (Group II) showing positive reaction in the tubules (arrows) and Bowman's capsules (arrow heads). A weak reaction in the brush borders of proximal convoluted tubules (arrows with double heads) is noticed. (PAS X400).

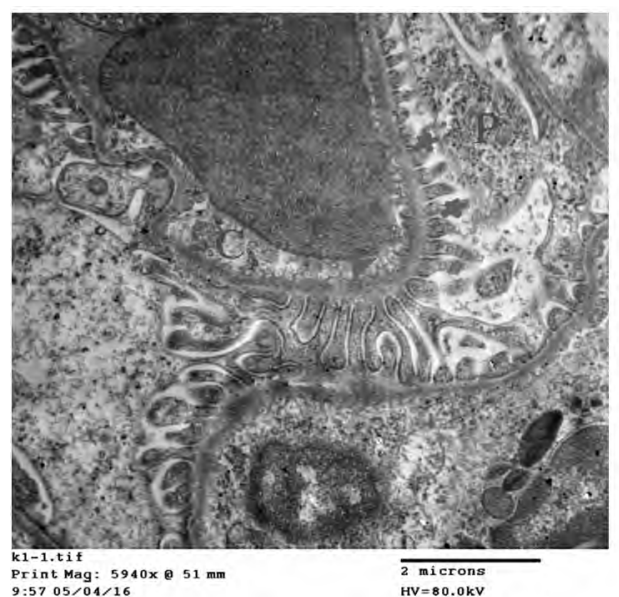

Fig. (13): An electron micrograph of a portion of renal glomerulus in kidney of Treated rat (Group II) showing; thickening in the basal lamina (arrow head), destructed podocyte $(\mathrm{P})$ with pedicles (asterisks) and glomerular capillary (C). (X10,000).



Fig. (15): A transmission electron micrograph from a section in the renal cortex of a treated rat (Group II) showing the lining epithelial cells of distal convoluted tubule with ill defined border, destructed cytoplasm with multible vacuoles $(\mathrm{V})$, resting on a thickened basement membrane (arrow head), multible swollen mitochondria (M) and oval heterochromatic irregular border nucleus (N). (X4800).

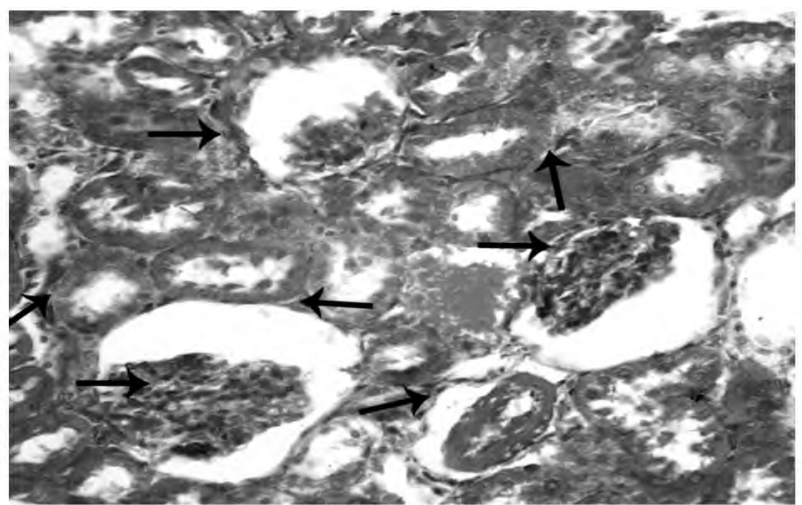

Fig. (12): A photomicrograph of a section of kidney of treated rat (Group II) showing great amount of collagenous fibers in the cortical tissue (arrows). (Masson's Trichrome stain X400).

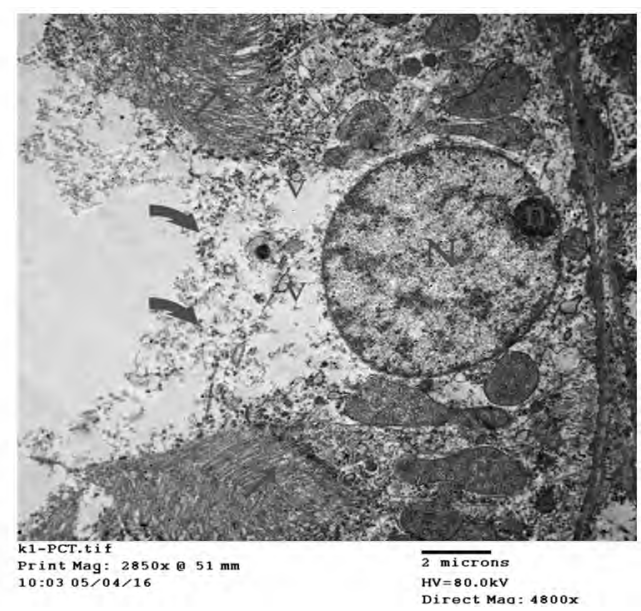

Fig. (14): An electron micrograph of from a section in the renal cortex of treated rat (Group II) showing epithelial cell of proximal convoluted tubule in kidney with ill defined border and destructed apical part and destructed brush border (curved arrows), with mulible vacuoles (V), relatively thick basement membrane (arrow head). Multible swollen mitochondria (M), heterochromatic nucleus (N), nucleolus (n) and Note: Area with normal brush border (arrows) (X4800).



Fig. (16): A photomicrograph of a section of kidney of treated rat (Group III) showing; renal glomerulus (G) appeared with near normal shape, normal urinary space (U), other glomeruli appear shrunken and irregular in shape (asterisks) with mild dilatation of urinary space, partial loss of the bush border of proximal convoluted tubules (P), near normal shape distal convoluted tubules (D) and mininimal interstitial haemorrhage (thick arrow). (H \& E X400). 


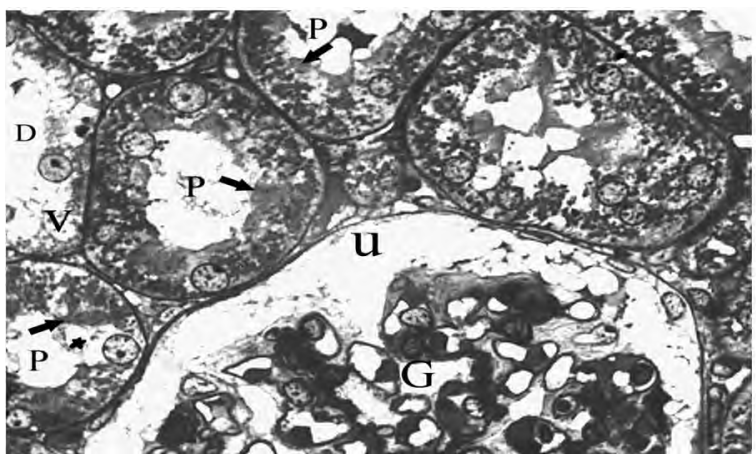

Fig. (17): A photomicrograph of semithin section in kidney of treated rat (Group III) showing; proximal convoluted tubules $(\mathrm{P})$ with partial loss of their brush borders (asterisk), brush border (thick arrows), areas with partial destruction of brush borders and Glomerulus (G) with near normal capsular space (U) and vacculation of the cells of distal convoluted tubules (V). (Toluidine blue X1000).

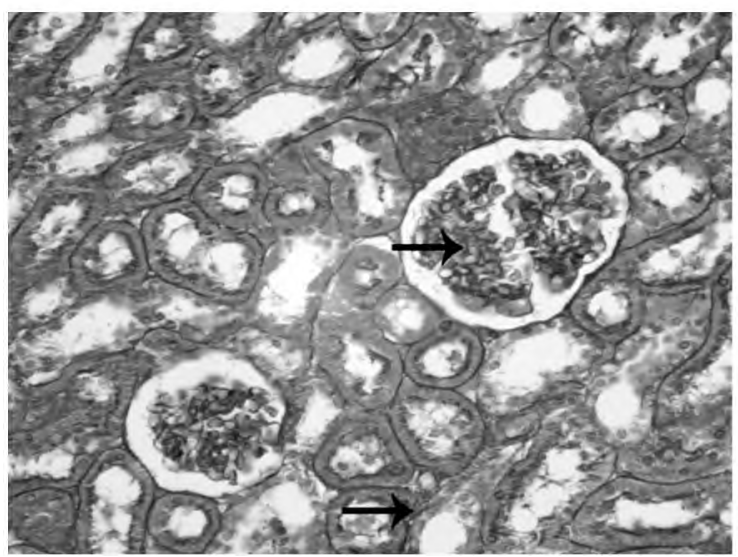

Fig. (19): A photomicrograph of a section of kidney of treated rat (Group III) showing reduction of the amount of collagenous fibers in the cortical tissue than Group II (arrows). (Masson Trichrome stain X400).

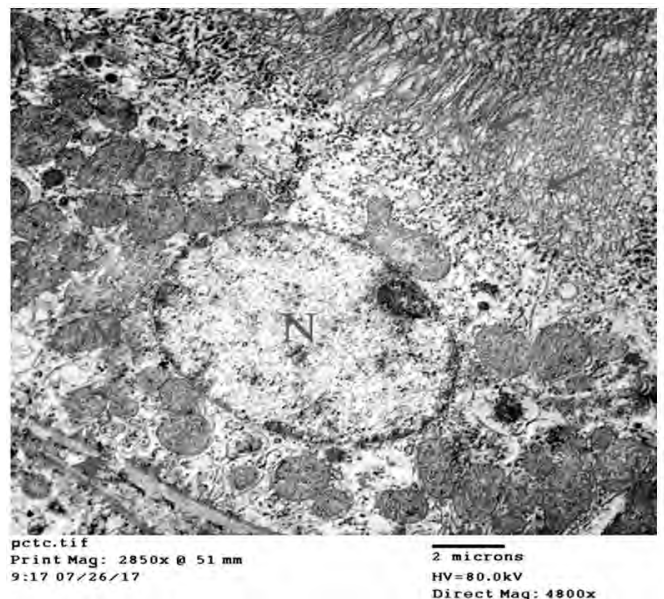

Fig. (21): A transmission electron micrograph from a section in the renal cortex of Vitamin C (Group III) supplemented group showing epithelial cell of proximal convoluted tubule showed restoration of its normal shape with intact brush border (arrows), resting on basement membrane with restoration of its normal thickness (arrow head), noramal rounded euchromatic nucleus $(\mathrm{N})$ with prominent nucleolus (n), multible swollen mitochondria (M) still present. (X4800).

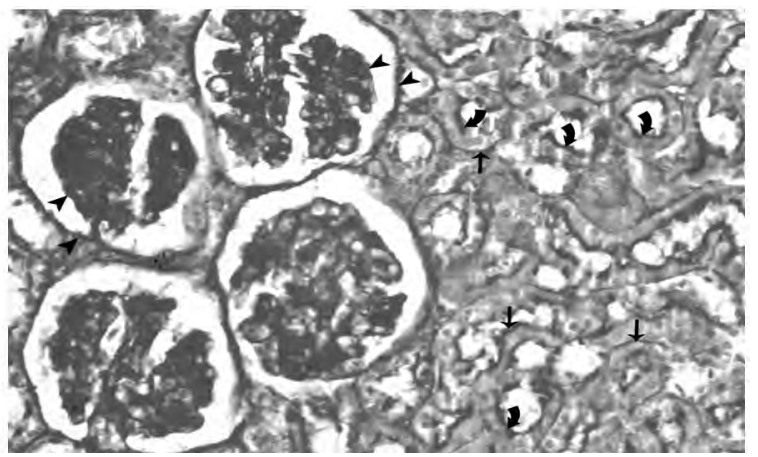

Fig. (18): A photomicrograph of a section in the renal cortex of Vitamin C supplemented group (Group III) showing moderate positive reaction of Bowman's capsule (arrow head) and basement membrane of proximal and distal convoluted tubules (arrows). A variable strong reaction in the brush border of proximal convoluted tubules (curved arrow) was seen. (PAS X400).

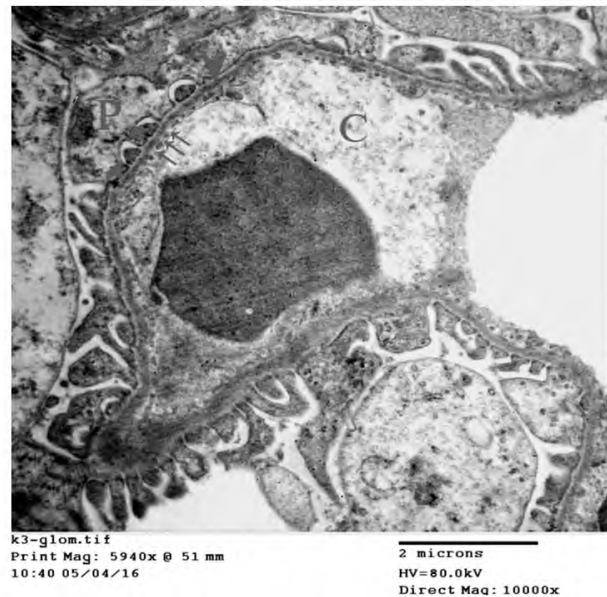

Fig. (20): A transmission electron micrograph from a section in the renal cortex of Vitamin C supplemented group (Group III) showing the restoration of normal shape of glomeruli with normal thickness of glomerular basement membrane (arrow head), podocyte (P) with normal shape, multiple foot processes (asterisks) around glomerular capillary (C) and fenestrations (thin arrows) are seen. (X10000).



Fig. (22): A transmission electron micrograph from a section in the renal cortex of Vitamin C supplemented group (Group III) showing epithelial cell of distal convoluted tubule restores its normal shape with well defined border, cytoplasm filled with mitochondria (M), nucleus $(\mathrm{N})$ appeared with well defined border and basement membrane with relatively normal thickness (arrow head). (X4800). 
Table (1): Showing the mean diameter (in pixels) of glomerulus, PCT and DC.

\begin{tabular}{|c|c|c|c|c|c|c|}
\hline Parameters & GI & GII & GIII & $p_{1}$ value & $p 2$ value & $p$-value \\
\hline Diameter of glom (Pixels) & 564.0786 & 551.7459 & 578.2498 & 0.806 & 0.776 & 0.73 \\
\hline Diameter of PCT (Pixels) & 261.6362 & 326.9511 & 323.5516 & $0.000 * * *$ & $0.000 * * *$ & $0.00 * * *$ \\
\hline Diameter of DCT (Pixels) & 380.1822 & 668.6593 & 406.2594 & $0.000 * * *$ & 0.463 & $0.00 * * *$ \\
\hline
\end{tabular}
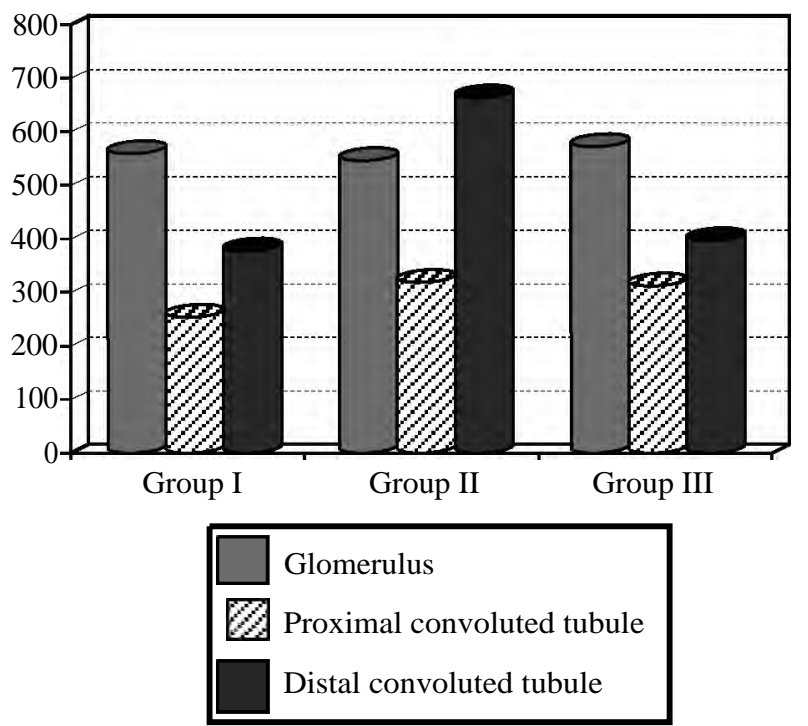

Diagram (1): Showing the mean diameter (in pixels) of glomerulus, PCT and DCT.

\section{Discussion}

The kidney is rich in glutamate receptors so becomes target for glutamate in MSG [10,11]. The MSG, in the blood, dissociated into sodium and glutamate. The glutamate is filtrated though the renal corpuscles and passed in the convoluted tubules of the cortex so they become liable to the toxic effects of MSG [12].

The changes of the renal cortex after MSG treatment was confirmed by previous studies which showed degenerated glomerular capillaries tufts and widened Bowman's space in kidneys treated with MSG [11,12].

On studying the effect of MSG on the kidneys researches found that there were areas of interstitial haemorrhage and congested blood capillaries in rats treated with high dose MSG [13,14] .

Another study showed destruction of the brush border of PCT with loss of its brush border, vacculation of the cells of PCT \& DCT and widened of their lumena in rats treated with MSG $[\mathbf{1 5 , 1 6}]$.
Lipid peroxidation following MSG treatment leads to loss of membrane integrity and vascular endothelial damage [17]. The increase in the nitric oxide production follow the MSG treatment cause vascular congestion as it is a powerful vasodilator [10].

The mechanism of tubular injury is mainly due to the oxidative stress which detected by excessive production of Free Radicals (FR) and Reactive Oxygen Spices (ROS) [18]. The ROS generation causes cellular injuries as they reacts with polyunsaturated fatty acids of cell membrane leading to peroxidation of unsaturated fatty acids in the biological membranes, depolymerization of polysaccharides, inactivation of the cellular enzymes and induction Deoxyribonucleic Acid (DNA) breaks $[19,20]$

Cellular degeneration has been reported to result in cell death which is of two types namely apoptosis and necrotic cell death [21].

The strong reaction in Bowman's capsules and the basement membrane of PCT \& DCT, a weak reaction in the brush border of PCT as the MSG induced hyperglycemia that enhanced type IV collagen production which is the main components of the basement membranes [10,22]

EM results of MSG treated group were confirmed by previous study which reported that the proximal tubules showed swollen mitochondria and small vacuoles in rats treated with MSG [10].

The increase in the thickness of the basement membranes of glomeruli, proximal and distal convoluted tubules was explained by the theory that MSG induced hyperglycemia that enhanced type IV collagen production which is the main components of the basement membranes [22].

In the current study administration of Vitamin $\mathrm{C}$ presented a protective effect against MSG as it decreased the accumulation of the connective tissue and restored the carbohydrate contents. These results concour with previous studies which showed 
that positive PAS reaction indicating restoration of carbohydrate content and reported also that there was reduction in the amount of collagen fibers in vitamin C-MSG s supplemented group as compared with MSG treated group [23-25].

Vitamin C decreases apoptosis of proximal tubular epithelial cells, degree of glomerular injury and tubulo-interstitial damage in diabetic rats without significantly affecting plasma glucose [26]

Dietary antioxidants such as Vitamin C, Vitamin $\mathrm{E}$ and queritn have a protective effect against oxidative stress induced by MSG $[27,28]$.

The electron microscopic results were confirmed by another study on the effect of Vitamin $\mathrm{C}$ on diapetic rat and found that it reduce the thickness of glomerular basement membrane as Vitamin C helped alleviation of the renal degeneration by protecting the glomerular structures from oxidative injury [29]

The results of the present study Vitamin CMSG treated rats showed that the apices of the PCT cells restored the microvilli, this was confirmed by a study which found [30].

Vitamin C exerts an inhibitory effect on the levels of lipid peroxidation of all examined kidney tissues of rats treated with Vitamin $\mathrm{C}$ after MSG that restored the membrane integrity of PCT and DCT [25].

\section{Conclusion:}

- Monosodium Glutamate (MSG) causes toxic effects on the renal cortex as atrophy of renal glomeruli and loss of the brush border of PCT and dilatation of DCT.

- Vitamin C can improve these toxic changes occurred by MSG on the kidney tissue as restoration of the size of glomeruoli and tubules.

\section{References}

1- AL-SAMAWY E.R.M.: Morphological and Histological Study of the kidneys of the Albino Rats: Al Anbar J. Vet. Sci., Vol. 5 No. (1): 1999-6527, 2012.

2- YAMAGUCHI S. and NINOMIYA K.: Umami and food palatability. J. Nutr., 130: 921S-926S, 2000.

3- ERB: The slow poisoning of maniked. A report on the toxic effects of the food additive Monosodium glutamate to the joint FAO/WHO Experts Committee on food additives, 1-24, 2006.

4- BEYREUTHER K., BIESALSKI H.K. and FERNSTROM J.D.: "Consensus meeting: Monosodium glutamate-an update". Eur. J. Clin. Nutr., 61 (3): 304-13, 2007.
5- STEVENSON D.D.: "Monosodium glutamate and asthma". J. Nutr., 130: 1067S-1073S, 2000.

6- MOHAMED M.A., NOUR ELDIN N.M. and DARWISH I.E.: The possible protective effect of Vitamin C,E and L.Carnitine on monosodium glutamate induced oxidative stress in the rat, Bull. Alex. Fac. Med., 44 (1), 2008.

7- PADAYATTY S.J., KATZ A., WANG Y., et al.: "Vitamin $\mathrm{C}$ as an antioxidant: Evaluation of its role in disease prevention." Journal of the American College of Nutrition, 22 (1): 18-35, 2003.

8- MOHAMED K.I.: The Effects of Oral Dosage of Monosodium Glutamate Applied for Short-and Long-Terms on the Histology and Ultrastructure of Testes of the Adult Rats Journal of Animal and Veterinary Advances, 11 (1): 124-33, 2012.

9- OSMAN H., ELSHAMA S. and EL-KENAWY A.: Study of the role of antioxidant (Vitamin C) on modulation toxicity of chronicuse of monosodium glutamate in liver of albino rats. Ain Shams J. Forensic. Med. Clin. Toxicol., (19): 75-87, 2012.

10- SAKR A.A.: Light and electron microscopic studies on lung and myocardium of the mice fetuses maternally treated with monosodium glutamate and role of Vitamin E against toxicity. The Egypt. J. of Hospital Medi., 15: 95-117, 2004

11- EWAKA: Histological studies of the effects of monosodium glutamate on the kidney of adult wistar rats. Inter. J. of Healt, 6 (2): 106-9, 2007.

12- ORTIZ G.G., QUINTERO B., ZÁRATE O.K. RODRÍGUEZ C.B. and LARIOS S.: Monosodium glutamate-induced damage in liver and kidney: A morphological and biochemical approach. Biomed. Pharmacother., 60 (2): 86-91, 2006.

13- FARR A.M., JUNG A. and SCHIOPU A.: Possible implications of monosodium glutamate in development of obesity and some liver diseases. J. of Exper. Medi. \& Surg. Research, 138-40, 2010.

14- IBRAHIM M.A., BUHARI G.O., ALIYU A.B., YUNUSA I. and BISALLA M.: Amelioration of Monosodium Glutamate- Induced Hepatotoxicity by Vitamin C European Journal of Scientific Research, Vol. 60 No. 1 pp. 159-65, 2011.

15-EWEKA A.O. and OM'INIABOHS F.: Histological studies of the effects of monosodium glutamate on the liver of adult Wister rats. The Internet Journal of Gastroenterol., 6: 2-10, 2008.

16- THOMAS M., SUJATHA K.S. and GEORGE S.: Protective effect of Piper longum Linn. on monosodium glutamate induced oxidative stress in rats. Indian J. Exp. Biol., 47 (3): 186-92, 2009.

17- TSOU T.C., YEH S.C., TSAI F.Y. and CHANG L.W.: The protective role of intracellular GSH status in the arseniteinduced vascular endothelial dysfunction. Chem. Res. Toxicol., 17 (2): 208-17, 2004.

18-PAVLOVIC V., PAVLOVIC D., KOCIC G., SOKOLOVIC D., SARAC M. and JOVIC Z.: Ascorbic acid modulates monosodium glutamate induced cytotoxicity in rat thymus, Bratisl. Lek. Listy., 110 (4): 205-9, 2009. 
19- KHADING A.A., ATI S., MOHAMMED A.M. and MOHAMED H.E.: Response of boiler chicks to dietary monosodium glutamate. Paki. Vet. J., 29 (4): 165-8, 2009.

20- MINIBAYEVA F., KOLESNIKOV O., CHASOV A., BECKETT R.P., LÜTHJE S., VYLEGZHANINA N., BUCK F. and BÖTTGER M. PLANT CELL ENVIRON: Wound-induced apoplastic peroxidase activities: Their roles in the production and detoxification of reactive oxygen species; 32 (5): 497-508. Doi: 10.1111/j.13653040.2009.01944.x. Epub 2009 Jan. 22, 2009.

21- BRAUCHLE E., THUDE S., BRUCKER S.Y. and LAYLAND K.: Cell death stages in single apoptotic and necrotic cells monitored by Raman microspectroscopy Sci. Rep. 2014, 4: 4698.Published online 2014 Apr. 15. Doi: 10.1038/srep04698. European Journal of Scientific Research ISSN 1450-216X Vol. 60 No. 1, pp. 159-65, 2011.

22- JALALI M., NIKRAVESH M.R., MOEEN A.A., KARIMFAR M.H., SAIDINEJAT S. and SHABNAM M.I.: Inductive Role of Collagen Type IV During nephrogenesis in Mice Urology Journal, Vol. 6 No. 4 Autumn, 2009.

23- ATTIYA M.M.: Oxidative stress damage in the liver and kidney of male mice administered with chromium, protective role of melatonin and Vitamin C, M.Sc. thesis Department of Zoology, Faculty of Science, Assiut University, 2008.

24- YOUNES H.A.: Protective effect of melatonin and Vitamin $\mathrm{C}$ on Ethanol induced oxidative stress and morphological changes in male albino mouse, Ph.D. thesis Department of Zoology, Faculty of Science, Assiut University, 2010.

25- MAHMOUD A.B., AL YAFEI A.H., KHIDR B.M. and
EL-SHOKKARY G.H.: Role of melatonin and Vitamin $\mathrm{C}$ in ameliorating monosodium glutamate induced oxidative stress and morphological changes in rats M.Sc. thesis Department of Zoology, Faculty of Science, Assiut University, 2010.

26- LEE F.Y., MI YOUNG LEE, 2 SOON WON HONG,3 CHOON HEE CHUNG, 2 and SAE YONG HONG1: Blockade of Oxidative Stress by Vitamin C AmelioratesAlbuminuria and Renal Sclerosis in Experimental Diabetic Rats, Yonsei Med. J., 48 (5): 847-55, 2007.

27- GULTEKIN F., DELIBAS N., YASAR S. and KILINC I.: In vivo changes in antioxidant systems and protective role of melatonin and a combination of Vitamin $\mathrm{C}$ and Vitamin $\mathrm{E}$ on oxidative damage in erythrocytes induced by chlorpyrifos-ethyl in rats. Arch. Toxicol., 75 (2): 8896, 2001.

28- FAROMBI E.O. and ONYEMA O.O.: Monosodium glutamate-induced oxidative damage and genotoxicity in the rat: Modulatory role of Vitamin C, Vitamin E and quercetin. Hum. Exp. Toxicol., 25 (5): 251-9, 2006.

29- GANESH E., CHOWDHURY A., MALARVANT T. and ASHOK VARDHAN N.: Microscopic observation of kidney for ameliorative effects of vitamin $E \& C$ in streptozotocin induced diabetic rats 2 (3) Life Science Biochemistry international Journal of Life Science \& Pharma Research, 2012.

30- EL-GAMMAL A.A., AHMED F.E., EL-MOSALAMY K.H. and ERAUE H.M.: Histological study on the effect of monosodium glutamate on the renal cortex of adult male albino rats. M.Sc. thesis Department of Histology, Faculty of Medicine Zakazik University, 2011. 


\section{تآثيرات جلوتاميد آحادى الصوديوم على كلية ذكر الفآر البالغ

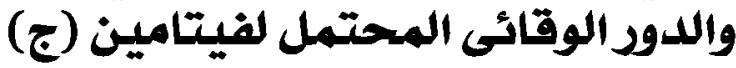

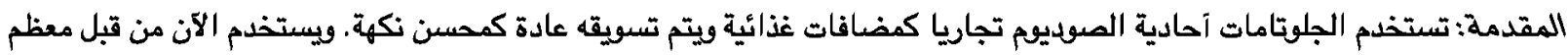



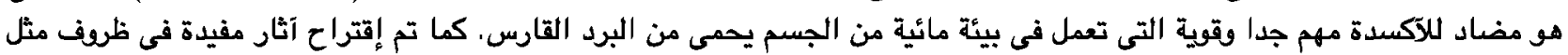
السرطان، وآمراض الآوعية الدموية، إعتام عدسة العين، والسكري، والريو، وإلتهاب المفاصل، ومرض في ماركنسون والتوحد والإكتئاب.

الفرض من البحث: دراسة التآثير الوقائى المحتمل من فيتامين ج على تلف الكلى الناجم عن الجلوتامات آحادية الصوديقم في الفئران الذكور البالغين.



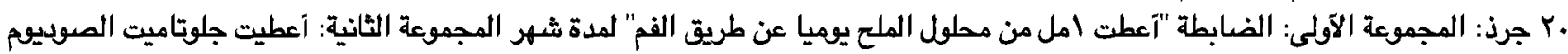



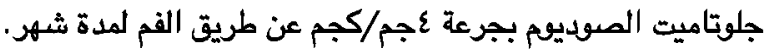

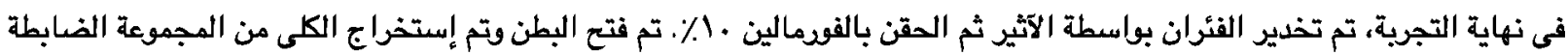
والصيوانات المعالجة وتجهيزها للفحص بالميكروسكوب الضوئي والميكروسكوب الإلكترونى النافذ.

النتأُج: حدث تلف بشكل ملحوظ لكبيات وآنابيب الكلى عندما فحصت بإستخدام الميكروبكوب الضوئى والإلكترونى وإضافة فيتامين

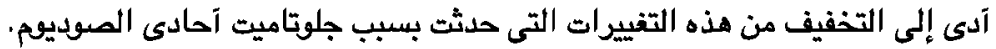

الخلاصة: الجلوتامات آحادية الصوديقم يسبب آثارا سامة على القثرة الكلوية. فيتامين C يمكن آن تحمى ضد هذه التفيرات السامة

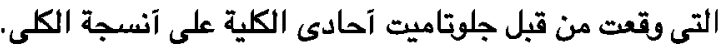

